tives or neighbours were, as a rule, willing to give information in response to a tactful inquiry concerning the fatal illness; in several other cases the general practitioner supplied such details. Sometimes the present occupier of the house spontaneously made inquiries and was able to trace the whereabouts of the patient. In no case was information refused. Only three patients who were physically able to attend the hospital refused to do so, but they were later visited at their homes.

In certain instances it was possible to trace individual cases on very scanty information. Thus, to cite an example, the occupier of the house where Case 255 formerly lived said that he did not know where the patient was, but he did know that his brother was a jockey with $\mathrm{Mr}$. X, at Newmarket. A telephone call to a firm of local turf commission agents was successful in obtaining the trainer's address. A letter was written to the trainer, who passed it on to the jockey concerned. The jockey replied that he had not seen his brother for years, but gave his mother's address. A letter to the mother was forwarded by her to the patient, who visited the hospital the following week. Similar mancuvres were necessary in tracing other cases, but eventually, with persistence, 159 patients were traced. Three of the remaining 13 cases were found with the help of the Tyneside Council of Social Service ; representatives visited the neighbourhood and were able to obtain the required information. Another eight were traced with the aid of a final-year student of the social studies department of King's College, who visited the patient's previous address and by tactful inquiry in the neighbouring houses and streets was able to discover what had happened to the patient in every case. Thus, in all, 170 patients of the 172 who were discharged from hospital were traced; the only two who could not be found were serving in the Army when admitted to this hospital, and, although lettèrs were forwarded to their last known addresses via the War Office, no replies were received.

Of the surviving 120 patients, 104 were questioned and examined by me, and the remainder, who were inaccessible, forwarded whatever information was asked of them.

I wish to thank the physicians of the Royal Victoria Infirmary for allowing me to consult their records and to examine their cases, and in particular I am grateful to Professor F. J. Nattrass for his advice and encouragement. I was able to examine the records of the Department of Neurosurgery, Newcastle General Hospital, through the courtesy of Mr. G. F. Rowbotham. I am also grateful to the many general practitioners in the Northeastern region who supplied information about their patients, and to Miss G. Nicholson, lady almoner of the Royal Victoria Infirmary, Miss Lois Armstrong, of the Department of Social Studies, King's College, and to the numerous others who gave invaluable aid in tracing surviving patients. I must also thank Mr. C. F. Naylor and the staff of the Records Department, the Royal Victoria Infirmary, for their help, and Miss Audrey Cairns, who carried the main burden of the large amount of clerical work involved.

REFERENCES

Ask-Upmark, B., and Ingvar, D. (1950). Acta med. scand., 138, 15 Baumoel, S. (1941). Anch. Neurol. Psychiat., Chtcago, 46, 1004.

Bleuler, M. (1951). British Medical Journal, 2 1233.

Credner, L. (1930). Z. ges. Neurol. Psychiat., 126, 721. Publishing Co., Ithaca, New York.

Denny-Brown D., (1945). J. Amer. med. Ass., 127, 429.

Denny-Brown, D. (1945). J. A mer. med.

Guttmann, E. (1946. J. ment. Sct., 92, 1.

Hamby, W. B. (1948). J. Amer. med. Ass., 136, 522

Hyland, H. H. (1950). Arch. Neurol. Psychlat., Chicaso, 63, 61.

Magee, C. G. (1943). Lancet, 2, 497.

Penfield, W. and Shaver, M. (1945). Proc. Ass. Res. nerv. Dis., 24, 620

Richardson J. C. and Hyland, H. H. (1941). Medicine, 20, 1.

Roen S. R. Arch. Neurol. Psychiat. Chicago, 50,350

Rowhotham, G F (1942). Acute Inturles of the Head. Livingstone, Edinburgh

Band Oaivie A. G (1945). Brtish Medtcal Journal, 1, 146

Russell, W. R. (1942). Ibid., $2,521$.

Sands, I. J. (1941). Arch. Neurol. Psychlat., Chtcaso, 46, 973.

Symonds, C. P., and Russell, W. R. (1943). Lancet, 1, 7.

Taylor, A. B., and Whitfield. A. G. W. (1936). Quart. J. Med., 5, 461

Walton, J. N. (1952a). To be published.

- (1952b). To be published.

- (1952c). Electroenceph. clin. Neurophysiol. In press.

Wieder A. Mittelmann, B., Wechsler, D. and Wolff, H. G. (1944)

J. A. med Ass. 124, 224

Wolf. Amer. A., Goodell, H., and Wolff, H. G. (1945). Ibid., 129, 715.

\section{INTRA-ARTERIAL INJECTIONS IN THE TREATMENT OF PERIPHERAL VASCULAR DISEASE}

\author{
BY
}

\author{
J. W. L. EDWARDS, M.D., M.R.C.P. \\ N. B. JONES, M.B., M.R.C.P. \\ R. B. MCCONNELL, M.B., M.R.C.P. \\ H. S. PEMBERTON, M.B., F.R.C.P.
}

AND

D. C. WATSON, M.C., M.D., M.R.C.P.

(From the Peripheral Vascular Clinic, David Lewis Northern Hospital, Liverpool)

The arterial route for the introduction of therapeutic substances has been used since the turn of the century in a wide field of disease. In 1899 Parlaveochio treated a severe infection of the limbs by injection of antiseptic solutions into the brachial and femoral arteries. Leriche and others used intra-arterial injections from 1913 onwards for the administration of specific antisera. The pioneer work of Sicard and Forestier (1923) in the introduction of relatively innocuous radio-opaque materials into the arterial tree encouraged the use of this route for therapeutic agents. Intra-arterial vasodilator substances were apparently first used by Singer in 1943, and since this time numerous workers have used this method to improve the peripheral circulation with varying success. Their cases were varied, but all showed features of ischaemia. When success was obtained it was believed to be due to reduction of vasoconstriction as well as to the opening up of collateral channels.

\section{Present Investigation}

The present series consists of patients with organic occlusive arterial disease, subdivided into two broad groups: those presenting symptoms primarily of intermittent claudication and those in whom ischaemic necrosis was paramount. All patients with manifest coronary artery disease were excluded. A number of vasodilator substances have been used, with the aim of improving exercise tolerance in intermittent claudication or limiting the development of ischaemic necrosis. Table I shows the total number of cases which received treatment by this means, divided into the two above-mentioned groups for age and sex.

TABLE I

\begin{tabular}{|c|c|c|c|c|c|}
\hline & \multicolumn{2}{|c|}{ Over 50} & \multicolumn{2}{|c|}{ Under 50} & \multirow{2}{*}{ Total } \\
\hline & Male & Female & Male & Female & \\
\hline $\begin{array}{l}\text { Intermittent claudication } . . \\
\text { Ischaemic necrosis }\end{array}$ & $\begin{array}{l}49 \\
18\end{array}$ & 8 & $\begin{array}{l}6 \\
1\end{array}$ & $\begin{array}{l}0 \\
0\end{array}$ & $\begin{array}{l}57 \\
27\end{array}$ \\
\hline
\end{tabular}

The success of this method can be assessed in a number of ways, and we employed the following : (1) clinical ; (2) variation in oscillometry; (3) exact estimation of exercise tolerance (walking) by means of the claudicometer ; and (4) immediate thermometric response.

Clinical-Assessment by the patient of betterment was received critically. Good clinical criteria of improvement were: increased warmth, lessened pain both at rest and after exercise, nearer approach to normal colour, and evidence of healing. 
Variation in Oscillometry.-Pachon's oscillometer was used throughout the investigation for determination of the existence of arterial pulsation or of any variation in amplitude after treatment. We have found it convenient to set down our results, in arbitrary units, as follows :

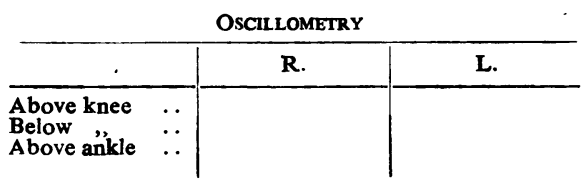

Claudicometry.-Exercise tolerance was measured by a machine with a moving platform originally described and called a claudicometer by Boyd (1949), and made for our clinic by Messrs. R. A. Loder and Co., of Manchester. The exact distance walked at any set speed can be measured accurately in yards, and the results are recorded as follows:

\begin{tabular}{|c|c|c|}
\hline \multicolumn{3}{|c|}{ ClaUdicometry............m.p.h. } \\
\hline & $\mathbf{R}$. & L. \\
\hline $\begin{array}{l}\text { Onset pain } \\
\text { Stopped } \\
\text { Recovery time } . .\end{array}$ & $\begin{array}{l}\text { yd. } \\
\text { yd. } \\
\text { min. }\end{array}$ & $\begin{array}{r}\text { yd. } \\
\text { yd. } \\
\text { min. }\end{array}$ \\
\hline
\end{tabular}

Immediate Thermometric Response.-The Cambridge skin temperature meter ("unipivot" model) was used for this purpose. Skin electrodes were placed on the foot, calf, and thigh of the affected $\operatorname{limb}$, with controls on the opposite side. Readings were taken immediately before the injection, immediately after the injection, and serially for one to two hours.

\section{Technique}

We originally employed the pressure drip method as described by Mufson (1948), but more recently, except in the case of drugs which need considerable dilution, we have found a needle and $20-\mathrm{ml}$. syringe to be adequate. No special preparation of the patient, no local analgesia, and no incision were found to be necessary. A sharp-pointed short-bevelled needle, preferably size 19 B.w.G. and $2 \frac{1}{2} \mathrm{~cm}$. long, with syringe attached, is plunged direct into the femoral artery. This manœuvre is more readily accomplished, particularly in the obese patient, by directing the needle against the blood stream. In the case of alcohol and histamine the drip method, taking approximately 30 minutes, was used, but a rapid injection of tolazoline, acetylcholine, and papaverine by the syringe method appeared to have no disadvantages. Accuracy of arterial puncture, of particular importance in the case of drugs such as acetylcholine which have undesirable side-effects when introduced intravenously, is facilitated by elevation of the pelvis and extension and external rotation of the limb. The procedure is safe and straightforward enough to be suitable for outpatient practice : the patients may safely be allowed to go home within a short time of the injection. For the period of eighteen months since the start of this work no aneurysms have developed, and only in one instance has a venous thrombosis occurred.

\section{Substances Used}

A number of substances, some of which we believe to be new in the field of intra-arterial therapy, are set out in Table II. It will be noticed that five drugs are placed in the first group and a greater number in the second. We received little or no encouragement to pursue the use of the latter, as benefit could not be demonstrated clinically or instrumentally in the small number of patients under observation.

Tolazoline (Benzyl-imidazoline; "priscoline").-The intra-arterial use of this substance is already well known, having been originally used by Singer (1943), and later by Lynn (1950), amongst others. It was noted that in addition to the local dilatation there was an almost immediate general response, as shown by flushing of the face and occasional
TABLE II

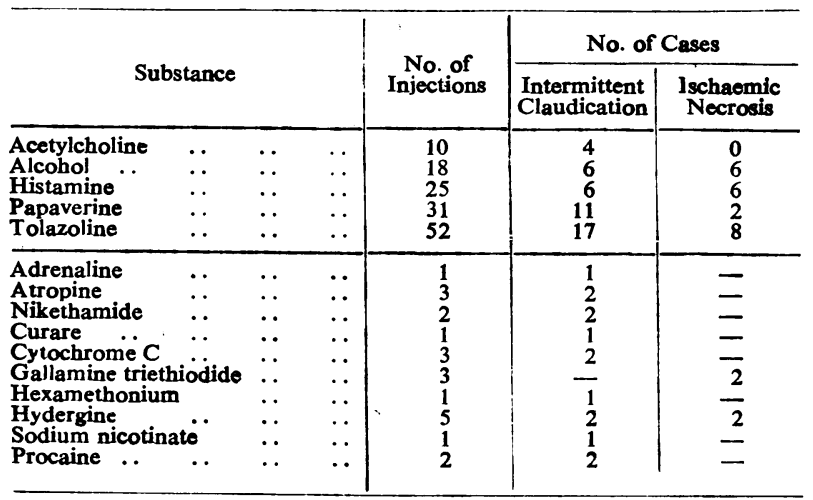

shivering, but no other side-effects. It has proved to be one of the best vasodilators we have used, in a dosage of $50-100 \mathrm{mg}$. in $10-20 \mathrm{ml}$. of saline.

Papaverine.-This appears to have been originally used intra-arterially by Singer in the form of "eupaverin." We used a dosage of $40 \mathrm{mg}$. of the sulphate in $20 \mathrm{ml}$. of saline. Side-effects were less than in the case of tolazoline, and, although there was not so much immediate superficial flushing of the limb, the results appeared to be as good.

Alcohol.-We cannot find any previous reference to the intra-arterial use of this well-known vasodilator, despite its established place in the treatment of peripheral vascular disease. An interesting phenomenon which we saw repeatedly was the entire absence of central effect, and in one case we were unable to demonstrate any alcohol in the returning venous blood at varying times after arterial introduction. The dosage of $15-20 \mathrm{ml}$. of absolute alcohol in $150-180 \mathrm{ml}$. of saline was given by the pressure-drip method. No side-effects were noted, but the results were not. so good as with the two previous substances.

Acetylcholine.-This seems to have been first introduced by Singer in 1943, and since that time it has been used by Oudot (1947) and Stolte (1950) in varying dosage. We found results were better with higher doses, such as $100 \mathrm{mg}$. in $5 \mathrm{ml}$. of saline, but they were not comparable to those in the case of tolazoline and papaverine. No side-effects were noted apart from transient blurring of vision in one case.

Histamine.-This substance appears to have been used originally by Mufson (1948), and was later described by Mackey (1950) in 12 cases. Our experience leads us to believe that it is of some value in a dosage of $3 \mathrm{mg}$. of histamine acid phosphate in $150 \mathrm{ml}$. of saline drip.

Tables III and IV summarize the results-in cases of both intermittent claudication and ischaemic necrosis-which we obtained with the use of these five substances. In amplification of these tables representatives cases are described for each substance used (numbered 1-9).

TABLE III.-Intermittent Claudication

\begin{tabular}{|c|c|c|c|c|c|c|}
\hline \multirow{2}{*}{$\begin{array}{l}\text { Case } \\
\text { No. }\end{array}$} & \multirow{2}{*}{$\begin{array}{l}\text { Substance } \\
\text { Used }\end{array}$} & \multirow{2}{*}{$\begin{array}{l}\text { No. of } \\
\text { Cases }\end{array}$} & \multicolumn{3}{|c|}{ Improvement } & \multirow{2}{*}{$\begin{array}{l}\text { Immodiate } \\
\text { Thermo- } \\
\text { metric } \\
\text { Response }\end{array}$} \\
\hline & & & Clinical & $\begin{array}{l}\text { Oscillo- } \\
\text { metric }\end{array}$ & $\begin{array}{c}\text { Claudico- } \\
\text { metric }\end{array}$ & \\
\hline $\begin{array}{l}1 \\
2 \\
3 \\
4 \\
5\end{array}$ & $\begin{array}{l}\text { Acetylcholine } \\
\text { Alcohol } \\
\text { Histamine } \\
\text { Papaverine } \\
\text { Tolazoline }\end{array}$ & $\begin{array}{r}4 \\
6 \\
6 \\
11 \\
17\end{array}$ & $\begin{array}{r}2 \\
3 \\
4 \\
8 \\
12\end{array}$ & $\begin{array}{l}0 \\
2 \\
0 \\
2 \\
2\end{array}$ & $\begin{array}{r}1 \\
4 \\
5 \\
8 \\
13\end{array}$ & $\begin{array}{r}3 \\
2 \\
6 \\
10 \\
15\end{array}$ \\
\hline
\end{tabular}

TABLE IV.-Ischaemic Necrosis*

\begin{tabular}{c|c|c|c|c|c}
\hline $\begin{array}{c}\text { Case } \\
\text { No. }\end{array}$ & $\begin{array}{c}\text { Substance } \\
\text { Used }\end{array}$ & $\begin{array}{c}\text { No. } \\
\text { of } \\
\text { Cases }\end{array}$ & $\begin{array}{c}\text { Clinical } \\
\text { Improvement }\end{array}$ & $\begin{array}{c}\text { Oscillometric } \\
\text { Improvement }\end{array}$ & $\begin{array}{c}\text { Immediate } \\
\text { Thermometric } \\
\text { Response }\end{array}$ \\
\hline 6 & $\begin{array}{l}\text { Alcohol } \\
7\end{array}$ & 6 & 1 & 0 & 1 \\
8 & $\begin{array}{l}\text { Histamine } \\
9\end{array}$ & 6 & 3 & 1 & 6 \\
Topaverine & 2 & 0 & 0 & 1 \\
\hline
\end{tabular}




\section{Case Reports}

Case 1.-A male pensioner, aged 68. Four months' pain in left calf on walking 280 yards. Has had tolazoline and vitamin E. No pulses below left femoral-calcified arteries ; no oscillations below left knee. Given three injections of acetylcholine in three weeks. Can now walk 610 yards at $1 \frac{1}{2}$ miles an hour.

Case 2.-A tram-driver aged 55. Pain in right calf on walking 220 yards. No previous treatment. No pulses below right popliteal : oscillations, minimal at right ankle. Two alcohol drips in one week. Can now walk 260 yards at 2 miles an hour. Oscillations improved; pulses returned below knee.

Case.3.-A retired pilot, aged 63. Eight years' pain in left calf on walking 60 yards. Has had "amechol " iontophoresis and T.E.A.B. No pulse below left femoral and right knee : oscillations minimal below knees. Given three injections of histamine into left femoral artery in one month. Can now walk 130 yards at 2 miles an hour. Pulses and oscillations unchanged.

Case 4.-A master butcher aged 70. Nineteen years' history of pain in right calf at rest and after walking 110 yards. Ten years' treatment by amechol iontophoresis: no pulses either leg below femorals and no oscillation at ankles. Given two injections of tolazoline and two of papaverine in six months. Can now walk 710 yards at 2 miles an hour without pain. Oscillation and pulses not improved.

Case 5.-A labourer aged 62, off work. Eight months' history of pain in left calf on walking $\mathbf{5 0}$ yards. Six months' treatment with tolazoline by mouth-not much improved; no pulses in left leg below femoral, minimal oscillations below knee, and none at ankle. Given three intra-arterial injections of papaverine and four of tolazoline in three months. Can now walk 880 yards at 2 miles an hour without pain. Oscillometry improved, but no pulses have returned. He was back at work after five injections.

Case 6.-A contractor aged 67. Intermittent claudication left calf for six months ; could walk 25 yards only; later, ischaemic necrosis of left foot. No pulses and minimal oscillations below left knee. Given two alcohol drips in two months ; ultimate amputation above knee.

Case 7.-A commercial traveller aged 71. Diabetic; necrosis of right big toe for six weeks with preceding intermittent claudication for two years; could walk 200 yards only. Oscillations minimal below knee; no pulses below right femoral. Three injections of histamine plus penicillin in two weeks. Amputation of toe; complete healing, and ultimately able to walk 880 yards at 2 miles an hour.

Case 8.-A woman aged 77. Gangrenous right foot; oscillations minimal below knee; no pulses below right popliteal. Three injections of papaverine in three weeks; later, above-knee amputation. Moderate amount of bleeding at operation, and stump healed well.

Case 9.-A male pensioner aged 67. Necrosis of left big toe after Keller's operation; no history of claudication, but pulsation absent below both femorals; oscillations all reduced. Six injections of tolazoline in six weeks: wound healed.

\section{Remaining Substances of the Second Group (see Table II)}

The use of adrenaline and atropine was prompted by some work by Burn and Dutta (1948). Adrenaline caused a marked rise in blood pressure and intense superficial vasoconstriction in the limb in a case of intermittent claudication. Atropine in two cases gave rise to rigors. The use of nikethamide was entirely empirical and intensely painful. Curare has been used by Enria et al. (1950), who studied its inhibitory action on the neuromuscular synapses of voluntary muscle ; they thought that this drug might also be efficacious in the treatment of obliterative arterial disease. We were unable to confirm improvement with curare (D-tubocurarine chloride), or with gallamine triethiodide ("flaxedil "), a synthetic curarizing agent, with the dosage used, $5 \mathrm{mg}$. and $50 \mathrm{mg}$. respectively. It was again observed, as in the case of alcohol, that there was no demonstrable central effect, though local transient paresis and obliteration of deep reflexes in the limb were a striking feature.

We have used cytochrome in conjunction with tolazoline in cases of ischaemic necrosis, with a view to further augmenting the oxygen supply to the tissues. The number of cases has been too small for an opinion about the possible advantages of this combination. Hexamethonium iodide in our hands reduced the blood pressure to alarming levels without any apparent local benefit. We used "hydergine" (a mixture of dihydroergocornine, dihydroergocristine, and dihydroergokryptine) in four patients, but could not substantiate the claim of Kappert (1949) and others, who obtained excellent results in a high percentage of cases. The only reference we can find to the use of sodium nicotinate intraarterially is by Catalano (1946), but in one case, and in a dosage of $30 \mathrm{mg}$. in $20 \mathrm{ml}$. of saline, we found it was not well tolerated. Procaine, also mentioned by Burn and Dutta as possessing adrenolytic and sympatholytic effects, was found in two cases to be neither clinically nor instrumentally beneficial, but owing to the smallness of the group its usefulness cannot be excluded.

\section{Discussion}

In cases of degenerative arterial disease one cannot produce, in the present state of knowledge, a reversal of the pathological process, but treatment can be directed towards facilitating compensatory mechanisms. One such method is by the use of vasodilator substances. Should these be permitted to act over the whole body, however, vasodilatation in the more normal vasculature may divert blood from the ischaemic limb. Adequate concentration at the site of the lesion is more readily attained intra-arterially than by other routes, and it has the additional advantage that side-effects are minimized. Vasodilatation is produced either by blocking sympathetic motor pathways by action on nerve terminals in the vascular smooth muscle or by counteracting the constrictor effects of chemical substances formed at myoneural junctions. Drugs are available with either or, in some cases, both these effects. In considering the relative merits of surgical sympathectomy and the method under discussion, it is important to determine to what degree the sympatholytic action is potentiated by local action on the smooth muscle of the small blood vessels. Swan's plethysmographic studies (quoted by Lynn, 1950) demonstrated increased blood flow in an already sympathectomized limb following the intra-arterial injection of $50 \mathrm{mg}$. of tolazoline.

On this theoretical basis, and from our own observations, we believe that the intra-arterial injection of vasodilator drugs offers a good alternative to more elaborate surgical procedures. A large proportion of patients precluded from sympathectomy by generally adopted criteria of age, general condition, etc., can now be offered a mode of treatment which, we find, produces better results than other forms of therapy available to them. In patients eligible for sympathectomy we feel that a therapeutic trial with a course of intra-arterial vasodilator drugs may in a proportion of cases render surgery unnecessary. Improvement may also be anticipated in the unfortunate patients whose symptoms persist or recur after sympathectomy.

In the opening months of the present investigation the method was approached with some hesitancy, but increasing experience and the absence of unpleasant sequelae have proved to us that intra-arterial injection in the lower limb is a safe procedure and, we believe, a valuable one. The optimum frequency of injections is best determined on an individual basis : weekly injections in the earlier stages, with wider spacing later, according to response, has been our practice. 


\section{Summary}

A series of cases of occlusive vascular disease is described in the management of which intra-arterial injections of vasodilator substances have been used and their relative values discussed.

Improvement in a large percentage of our patients has encouraged us in the use of this method on an increasing scale. It is well within the scope of out-patient procedures, and offers a beneficial and convenient aid in the treatment of peripheral vascular disease.

Acknowledgments are gratefully made to Mr. J. B. Oldham for his constant help, encouragement, and criticism, and also to Messrs. Boots, to Ciba Laboratories Limited, to Messrs. May and Baker, and to Sandoz Products Limited for the supply of drugs and literature.

\section{REFERENCES}

Boyd, A. M., et al. (1949). J. Bone Jt Surg., 31B, 345

Burn, J. H., and Dutta, N. K. (1948). Brit. J. Pharmacol., 3, 354.

Catalano, G. (1946) Ann. ital. Cir., 23, 1

Enria. G., et al. (1950). Arch. ttal. Chir., 73, 219

Kappert, A. (1949). Helv. med. acta, 16, 65

Leriche, R. (1913). Quoted by R. Dos Santos, Surgery, 1939, 5, 436

Lynn, R B. (1950). Lancet, 2. 676.

Mackey, W. A. (1950). British Medical Journal, 2, 1086

Mufson, I. (1948). Ann. Intern. Med., 29, 903.

Oudot, J. (1947). J. Chir., Paris, 63, 279.

Parlaveochio, G. (1899). Policlintico Sez. chir., 6, 66

Sicard, J. A., and Forestuer, G. (1923). C.R. Soc. Biol., Paris, 88, 1200

Singer, R. (1943). Wien. klin. W schr., 55, 260.

Stolte, J. B. (1950). Acta med. scand., 138, 341

\section{BLOOD TRANSFUSIONS IN PARAPLEGIC PATIENTS WITH TOXAEMIA}

BY

\section{J. J. WALSH, M.B., B.Ch.}

Senior Hospital Medical Officer at the Ministry of Pensions Spinal Injuries Centre, Stoke Mandeville Hospital, Aylesbury

Malnutrition is a common finding in spinal paraplegic patients. It occurs as a result of the depletion of the body's protein reserve, due to infection of the urinary tract and pressure sores, combined with poor appetite and consequent low food intake. The loss of protein oozing from the sores and urinary tract may vary from 5 to $50 \mathrm{~g}$. daily (Poer, 1946), and this can result in extreme degrees of malnutrition, as exemplified in numerous paraplegics on admission to this centre. The assessment of plasma proteins was not found to be a reliable guide to degrees of malnutrition in these patients, for persons with an extreme degree of emaciation comparable to that found in inmates of concentration camps may show a normal or only slightly diminished total value, although the albumin/globulin ratio is invariably altered and as a rule reversed.

If oozing of protein from sores and the urinary tract were the only factor in the development of malnutrition one would expect that its replacement by transfusion of plasma or synthetic preparations, such as "casydrol," would be effective in treating the malnutrition in these cases. However, experience gained in this centre has repeatedly shown that this is not so, as another and more important factor has to be considered-namely, the profound effect of sepsis on the haemopoietic system. These patients invariably show signs of anaemia, although the exact degree may be clouded by haemoconcentration following frequent vomiting. In most cases admitted with multiple bedsores, which are nearly always accom- panied by heavy urinary infection, the haemoglobin estimation shows a reading below $75 \%$ and often as low as $50 \%$. In such cases osteomyelitis of the underlying bone is the rule rather than the exception, and, as shown by $x$-ray examination, the amount of bone involvement is often far greater than would be expected from the size and appearance of the sores. Numerous paraplegics admitted from their homes or from other hospitals showed infiltration of the infection into the joints, leading to septic arthritis, and in some cases even resulting in complete disintegration of the head of the femur. It is our experience that such sepsis depresses haemopoiesis, and the resultant anaemia in turn renders the patient less able to overcome the infection, thus establishing a vicious circle.

Attention has previously been drawn to the profound effect which frequent blood transfusions have in combating the nutritional deficiency in paraplegics with toxaemia (Guttmann, 1945, 1946, 1949), and during recent years blood transfusions have become in this centre the most important routine method of restoring nutritional deficiency and promoting the healing of pressure sores in paraplegic patients. In this connexion it may be noted that the local treatment of sores and urinary infection alone, or even if combined with systemic chemotherapy and antibiotics, is infinitely less effective in these toxic cases than when preceded and accompanied by blood transfusions. Furthermore, in many cases of paraplegia the stage is reached when pressure sores are clean, urinary infection appears to be well controlled, and haemoglobin estimations are apparently satisfactory $(80-90 \%)$, yet the rate of healing of the sore is very slow or the condition may even become quite static. In such cases a blood transfusion is usually effective in promoting a quicker healing rate.

The number and frequency of transfusions and the amount of blood given at each transfusion depend, as would be expected, on the individual case, but, in general, the greater the area of ulceration and the more toxic the patient the more frequently are blood transfusions required. In the routine treatment of a new admission with extensive bedsores 3 to 4 pints (1.7 to 2.3 litres) of blood are given in the first few days, followed by a weekly transfusion of 1 to 2 pints $(0.6$ to 1.1 litres) until such time as the patient's clinical condition shows that he has overcome the toxaemia, and until his blood count remains high. In many such patients 20 , to 30 pints (11.4 to 17 litres) of blood were required in the course of 8 to 10 weeks, and in one particularly serious case of profound sepsis with 14 sores, including two open joints, 76 transfusions were given over a period of seven months before his condition was satisfactory and his blood picture stabilized.

One serious drawback was that numerous patients, after a variable number of whole-blood transfusions, developed undesirable reactions to subsequent transfusions, despite the fact that no incompatibility was demonstrable in vitro. Investigations were carried out with a view to overcoming the difficulty, and the purpose of this paper is to draw particular attention to the encouraging results achieved with transfusions of redcell suspensions in such cases.

\section{Method and Material}

In all cases stored blood of homologous group, one to ten days old, was used, and it has been our experience that the fresher the blood the more efficacious was the transfusion. The blood was supplied by the regional transfusion service. 